\title{
THE PROCESS OF CZECH LANGUAGE ACQUISITION BY FOREIGN PUPILS AT LOWER SECONDARY SCHOOL
}

Yvona Kostelecká, Antonín Jančařík

Charles University in Prague

\author{
Highlights \\ - $\quad$ The study results show that there is a significant difference between the needs of learners
}

\section{Abstract}

The study results show that there is a significant difference between the needs of learners. Learners from related linguistic areas reach the threshold level of language skills very quickly, whereas children with a very different language (in our case, children from Asia) reach the threshold level of receptive skills quickly, but have big difficulties with productive skills. It is therefore necessary to focus on these areas and pay attention to this in Czech-language instruction. The study also shows that children who were born to foreigners in the Czech Republic or who moved to the country at a very young age do not usually have language problems that complicate their integration into the Czech school system, while children born outside the Czech Republic who move to the country at a later age face problems fulfilling the requirements of the school curricula, which are connected with their insufficient acquisition of the Czech language.

\section{Keywords}

Diagnostic test, foreign pupils, children, integration, language proficiency
Article type

Full research paper

Article history

Received: October 31, 2013

Received in revised form: March 18, 2014

Accepted: March 21, 2014

Available on-line: March 31, 2014

Kostelecka, Y. and Jančařík A. (2014) "The Process of Czech Language Acquisition by Foreign Pupils at Lower Secondary School”, Journal on Efficiency and Responsibility in Education and Science, Vol. 7, No. 1, pp. 7-13, online ISSN 1803-1617, printed ISSN 2336-2375, doi: 10.7160/eriesj.2013.070103.

\section{Introduction}

The Czech educational system in its modern post-war history has not had a great deal of experience with the integration of foreign children. Following the fall of the Iron Curtain, however, the number of foreign immigrants began to rise, with a particularly sharp increase following the accession of the Czech Republic to the European Union. Between 1985 and 2008 the number of non-nationals residing in the Czech Republic showed a more than ten-fold increase, with numbers increasing from 37,000, approximately $0.36 \%$ of the population, to almost 440,000 , over $4 \%$ of the national population (Drbohlav et al., 2010). Even though the global economic crisis has caused a significant decrease in the number of immigrants in the Czech Republic after 2008, the total positive balance of migration has remained at historically high levels (see Figure 1).

The fall of the Iron Curtain, and especially the period after the Czech Republic joined the European Union, gave rise not only to a change in migration numbers, but also to a change in the immigration structure. Short-term labour migration was progressively replaced by immigrants interested in long-term residency. There was an increase in the number of immigrants coming to the Czech Republic together with their families or who came with the idea of starting a family in the Czech Republic and having children. Czech society, and particularly the Czech educational system, now faces the problem of how to address this newly emerging situation. In the search for solutions to this new situation we can be inspired by the international experience of countries that have a long experience with the integration of foreign pupils in the education system. For example Coleman at al. (1966) deal with the equality of educational opportunity of foreign students in the USA, Vallet and Caille (1999) describe issues related to the integration of pupils of secondary schools in France, Spiess, Büchel and Wagner (2003) demonstrate the effect of age of the child entering school for the success of school integration. Our surveys carried out in primary schools ${ }^{1}$ in Prague in the years 2009, 2010 and 2011 (Kostelecká et al., 2010, 2011, 2012) point to the fact that one of the most important factors significantly affecting the successful integration of children with a foreign mother tongue into the Czech primary school system is the ability to communicate in Czech.

The research presented in this article focuses on the issue of the linguistic integration of foreign children into the Czech primary school system. It is a crucial topic because at school these children acquire a key skill: the ability to communicate in the language of the majority society. The ability to master the majority language at the age of compulsory education is in fact the key to success both at school and in the wider society later in life (Remennick, 2003). We concentrated at testing of the validity of two hypotheses about the way how children of foreigners are integrated into Czech school system. We hypothesized that children of foreigners that have been more exposed to the Czech language are doing better in terms of Czech language proficiency. Although the positive effect of length of residence in the host country on language proficiency of immigrants have been widely documented in the foreign literature (Carliner, 2000, Stevens, 1999, Espinosa and Massey,

For the purpose of this article, the term "primary school" will be used to define schools for children between the ages of 6 and 11, and "lower secondary school" for children between the ages of 11 and 15. These two levels make up the period of compulsory education in the Czech Republic. 


\section{Net migration}

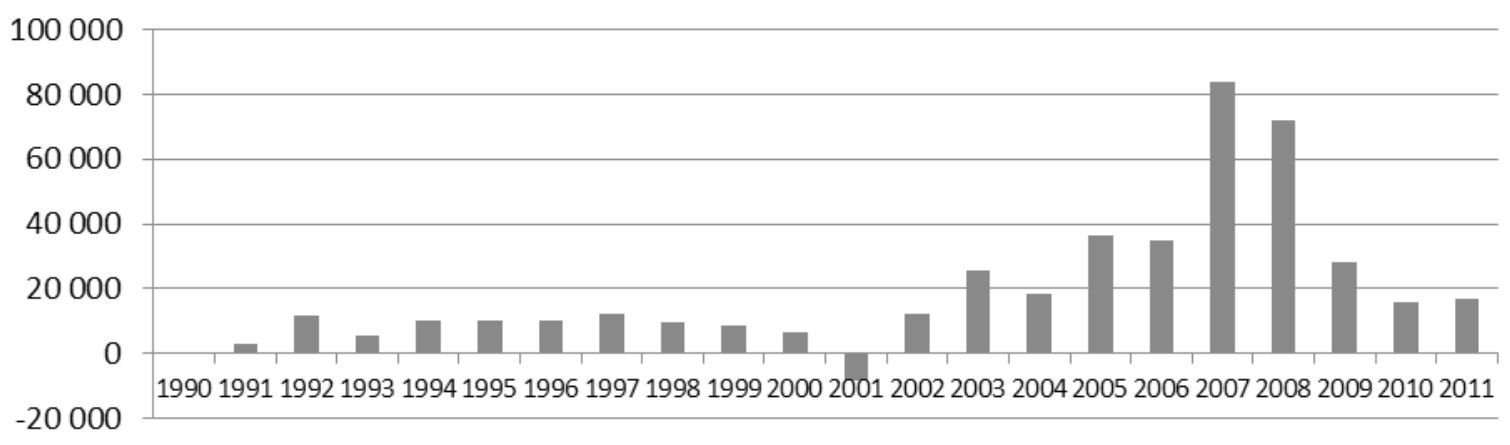

Figure 1: Balance of migration in the Czech Republic in the years 1990 -2011, source: CZSO (Population change in the Czech lands 1785 - 2011, absolute figures).

1997), this relationship was not analyzed among the pupils in the Czech primary schools. We also hypothesized that children from linguistically close language groups (Slavic) would acquire ability to use Czech language more quickly than children from linguistically more distant language groups (Asian). Number of studies prove that such relationships exist: Chiswick and Miller (1996) found that in Australia, Modoof et al. (1997) in the United Kingdom, Tribalat (1995) in France, and Hayfron (2001) in Norway to name some of them. Again, no such study has ever been conducted in the Czech Republic so far.

\section{Material and Methods}

To be able to achieve the above-stated objectives, we first had to develop a diagnostic tool with which to assess the language proficiency of the children tested in relation to the levels defined by the $\mathrm{CEFR}^{2}$ (Šára et al., 2001, Cvejnová, 2006, Cvejnová et al. 2007) which implies a certain level of independence in communication.

Adiagnostic test ${ }^{3}$ was designed so as to meet the recommendations of the CEFR, the European Language Portfolio for the given age group and the recommendations of the international affiliated organizations ALTE (The Association of Language Testers in Europe) and EALTA (European Association for Language Testing and Assessment). ${ }^{4}$ The diagnostic test was developed to be applicable from zero knowledge of the language to level B2, for children in lower secondary schools. Subtests included all language skills, i.e. both receptive skills, such as reading and

$2 \quad$ CEFR - Common European Framework of Reference for Languages: Learning, Teaching, Assessment (Council of Europe, 2011).

3 Each diagnostic test consisted of specifications, a recording script for the diagnostic test, recordings for the listening tasks, a script for the verbal part of the diagnostic test, assessment criteria, an answer key for the tasks, guidelines for examiners and instructions for the full version of the diagnostic test.

$4 \quad$ In the creation of the test we were taking inspiration from the diagnostic tests the Cambridge ESOL Examinations, English tests for young learners and also from Czech diagnostic tests, namely the Certified Examination in Czech for Young Learners, test developed by Cvejnová at al. (2007) and test for young learners developed by Kostelecká et al. (2011). In creating the tests we were also taking advantage of the experience in developing tests and test methods described in the technical literature (for example Harrison 1983, Davies 1990, Smith 1995, Hughes 2003, Hasselgreen 2005, Bachman, Palmer 2009). listening, and productive skills, such as speaking and writing. Not only did this tool help us to quantify the progress achieved by immigrant children over a given period of time, but it also enabled us to objectively estimate how much time they needed on average to master the language at the B1 threshold level, and to assess the impact of various types of factors on the speed of learning the language. We also took into consideration the children's nationality/native language and the length of their stay in the Czech Republic ${ }^{5}$. A total of 118 primary school pupils speaking 16 different native languages enrolled in 8 different schools took part in the tests. The schools that participated in the testing met the following selection criteria: they had a large number of foreign pupils and each was located in a different area of Prague (historical centre, inner city, suburbs). The research was a follow-up on a pilot survey similar to this one carried out in 2010 .

Reliability and internal consistency of tests were tested by different methods. As a measurement of the internal consistency of the test, an alpha coefficient (see Cronbach, 1951) and a splithalf reliability $(0.91)$ coefficient were computed (see Kuder and Richardson, 1937). The alpha coefficient $(\alpha=0.96)$ is higher than 0.9 , what can be considered as proof of excellent internal consistency of testing. The alpha coefficient is also higher than the split-half reliabilities (which equals to 0.91), which again shows that this test is reliable. The quality of the test is also confirmed by the very high score in the Spearman-Brown Prophecy test (score equals 0.95). To describe the language test results we used descriptive analysis (Horn, 1993). To measure the relationships between language test results and selected indicators describing individual children (length of stay in the Czech Republic, language distance between native language of tested children and Czech language) we used correlation and regression analyses. The more detailed description of actual methods that was used could be found in the specific parts of the text below. 


\section{Results}

First of all, the data obtained during the research confirmed, as expected, that the length of stay in the Czech Republic has a positive impact on the level of language proficiency of foreign children enrolled in Czech primary schools. The length of time spent in the Czech Republic had a positive impact on pupils' test performances in all categories. A moderate correlation $(>0.5$, see Table 1) was observed between the length of residence of a pupil in the Czech Republic and the child's achieved scores at each level of the test (A1, A2, B1, B2). There was also a strong correlation ( $>0.5$, see Table 2 ) between the length stay in the Czech Republic and the scores achieved by a child in the subtests dedicated to each language skill separately (listening, reading, writing, speaking). It appears that the length of time in the country has a higher correlation with the results obtained in tests at advanced levels (see Table 1). The length of stay in the country has more effect on the speaking and writing skills of a pupil (see Table 2) than on his ability to read and understand the spoken language (El-Hmoudová and Milková, 2012).

\begin{tabular}{|c|c|c|c|c|}
\hline & 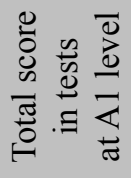 & 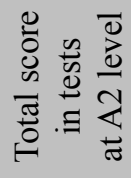 & 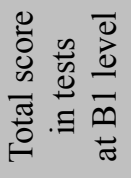 & 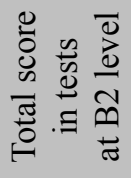 \\
\hline $\begin{array}{l}\text { Length } \\
\text { of stay }\end{array}$ & 0.509 & 0.565 & 0.596 & 0.588 \\
\hline
\end{tabular}

Table 1: Corellation (Pearson correlation coefficient ${ }^{6}$ ) between the lenght of stay in the Czech Republic and scores at different levels of the language test

\begin{tabular}{|c|c|c|c|c|}
\hline & 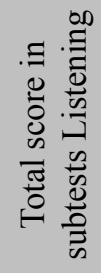 & 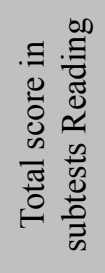 & 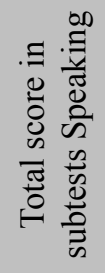 & 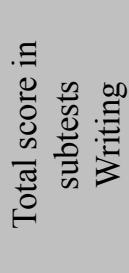 \\
\hline $\begin{array}{l}\text { Length } \\
\text { of stay }\end{array}$ & 0.503 & 0.521 & 0.613 & 0.561 \\
\hline
\end{tabular}

Table 2: Corellation (Pearson correlation coefficient) between the length of stay in the Czech Republic and scores at different subtests of the language test

We also sought to discover what is the necessary length of stay in the Czech Republic for foreign pupils to reach the threshold level. The test results show that with each added year of residency in the Czech Republic, the number of children who do not reach the threshold level decreases, at least in certain speech skills. Most pupils in lower secondary schools, who were living in the Czech Republic before entering the school system, attain the B1 level in all language skills (Table 3). Nevertheless, the testing showed that even those children who had lived a long time in the Czech Republic country and were attending a lower secondary school may have problems understanding some linguistic specifics, which are culturally conditioned (e.g. they do not understand proverbs).

$6 \quad$ The values of Pearson correlation coefficient can theoreticall vary between -1 and 1 . While value -1 means perfect inverse relationship and value 1 means perfect direct correlation, values around 0 indicate no relationships between variables.

\begin{tabular}{|l|c|c|c|c|c|}
\hline $\begin{array}{l}\text { Length of time } \\
\text { in the CR } \\
\text { (years) }\end{array}$ & $\begin{array}{c}\text { Lower than } \\
\text { A1 }\end{array}$ & A1 & A2 & B1 & B2 \\
\hline $0-1$ & 10 & 5 & 3 & 0 & 0 \\
\hline $2-3$ & 4 & 7 & 14 & 1 & 1 \\
\hline $4-6$ & 1 & 4 & 9 & 6 & 8 \\
\hline 7 and more & 1 & 1 & 13 & 13 & 17 \\
\hline
\end{tabular}

Table 3: Absolute number of children tested according to the highest attained language skill level and the length of time they had been in the Czech Republic (the level is attained when the success rate of each language skill subtest is at least $60 \%{ }^{7}$ )

During the survey we also observed the differences in the speed and the method of Czech-language acquisition by children whose native language belongs to the Slavic language family and is therefore related to Czech (53 pupils), and children who come from linguistically and culturally different regions, in our test these were children from an Asian background (58 pupils). It appears that learners whose background is in a language related to Czech have a strong advantage mainly during the first years they reside in the Czech Republic (see Figure 2) and reach a higher level earlier than learners from linguistically and culturally different (i.e. non-Slavic) backgrounds. Students from Asian countries who enter school upon arriving in the Czech Republic have absolutely no or almost no knowledge of the Czech language. These differences progressively disappear as the length of time in the Czech Republic increases.

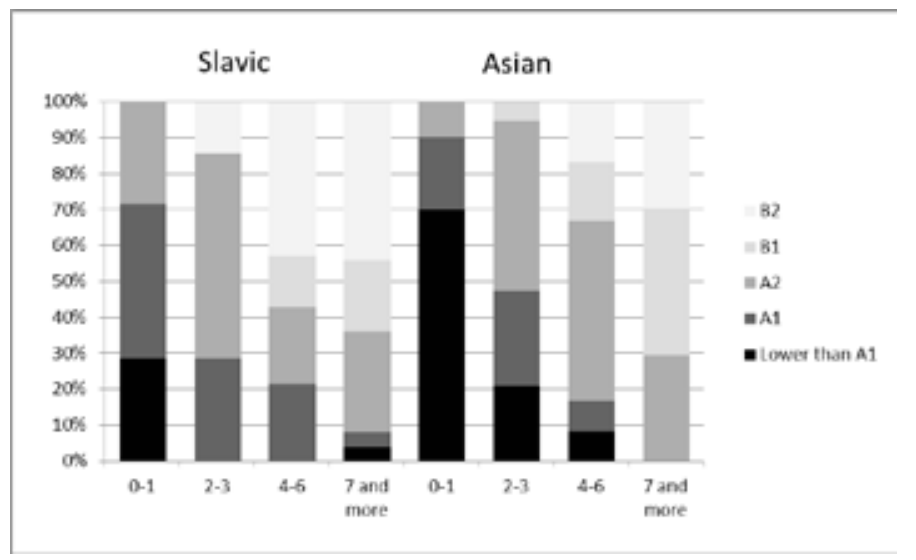

Figure 2: Highest attained language proficiency level of Slavic and Asian children according to their length of timey in years in the Czech Republic (the level is attained when the success rate of each language skill subtest is at least $60 \%$ )

The following figure (Figure 3) further specifies the process of learning Czech by Slavic and Asian children according to the length of time they had been in the Czech Republic. The figure shows that while almost half of the students from a Slavic language environment reached the B1 threshold level after about six to seven years of residing in the Czech Republic, only about $15 \%$ of children from an Asian background reached this level in the same period of time.

A tested pupil progressed to a higher level (A2, B1, B2) in each language skill only if he/she scored at least $60 \%$ in the lower level. 


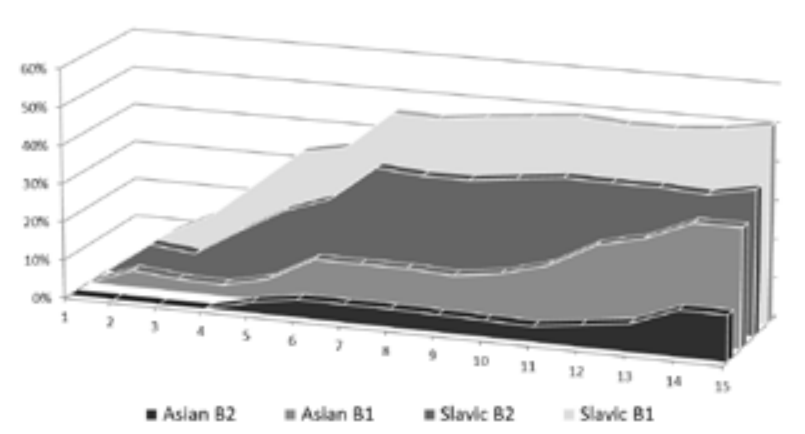

Figure 3: Proportion of Slavic and Asian pupils that reached level $B 1$ and $B 2$ according to their length of time in the Czech Republic (the level is attained when the success rate of the given level subtests is at least $60 \%$ )

We also sought to ascertain whether the development of language skills is homogeneous in all areas, or whether pupils improve in some areas faster than in others. The data suggest that pupils, particularly those with an Asia background, tend to acquire receptive skills (listening and reading) much more quickly than productive skills (writing and speaking) (see Figure 4). But even here, the differences dissolve with time.

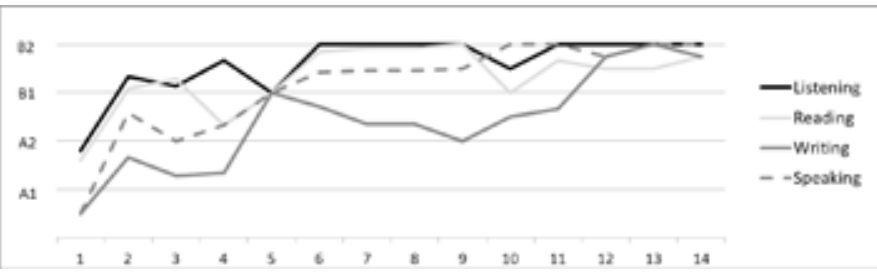

Figure 4: Achieved level in each language skill subtest for Asian pupils according to their length of time in the Czech Republic (the level is attained when the success rate of the given language skill subtest is at least $60 \%$ )

The question that is often discussed is to what extent the development of language skills is influenced by the age at which children arrive in the Czech Republic. Elementary school teachers who were interviewed during the research conducted at selected Prague schools in 2009 tend to claim that integration (including language integration) is generally much less of a problem for children who arrived in the Czech Republic at a very young age or were born in the Czech Republic (Kostelecká, 2010). We were interested whether the data that we collected support such claims. First, we selected 58 children of Asian background from the whole sample, as their age structure was favourable to our purposes. From this sub-sample we selected 51 children that formed three distinct subgroups:

- pupils that were born in the Czech Republic or arrived in the country during their first year of life (this subgroup consisted of 14 pupils)

- pupils that arrived in the Czech Republic when they were 10 to 11 years old, that is during the two final grades of elementary school (this subgroup consisted of 18 pupils)

- pupils that arrived in the Czech Republic when they were 12 years old or older, that is during the lower secondary school (this subgroup consisted of 19 pupils).

- The language testing provided information on each pupil's highest attained level of language proficiency. Information about that is provided separately for the three above-defined subgroups in Table 4.

\begin{tabular}{|l|c|c|c|c|c|}
\hline \multirow{2}{*}{$\begin{array}{l}\text { Age of arrival in the } \\
\text { Czech Republic }\end{array}$} & \multicolumn{5}{|c|}{$\begin{array}{c}\text { The highest attained level of } \\
\text { language proficiency }\end{array}$} \\
\cline { 2 - 7 } & $\begin{array}{c}\text { Lower } \\
\text { than } \\
\text { A1 }\end{array}$ & A1 & A2 & B1 & B2 \\
\hline $0-1$ years & 0 & 0 & 0 & 1 & 13 \\
\hline $10-11$ years & 1 & 0 & 1 & 4 & 12 \\
\hline 12 years and older & 2 & 3 & 2 & 7 & 5 \\
\hline
\end{tabular}

Table 4: Absolute number of children tested according to the highest attained levels of language proficiency and the age at which they arrived in the Czech Republic (the level is attained when the success rate of each language skill subtest is at least $60 \%{ }^{8}$ )

It is clear from the table that the language skills of Asian pupils that were born in the Czech Republic or arrived in the country as babies were generally at the $\mathrm{B} 2$ level in the case of those of lower secondary school age at the time the testing was organized. This language skill level seems to be high enough and does not limit the pupil's ability to fulfil school requirements. In contrast, the pupils who moved to the Czech Republic at the age of 12 or higher and therefore started attending lower secondary school more or less immediately after their arrival generally attained a much lower level of language proficiency when they were tested. It is not surprising but rather self-evident. We know that the level of language proficiency increases with the increasing length of stay of the children in the Czech Republic and, obviously, children who were born in the Czech Republic or moved to it at a very young age had spent more years in the country before entering lower secondary school than those who had arrived to the country at an older age.

But how do the language skills of pupils develop during the time period that corresponds with lower secondary school? As we do not have panel data that would allow us to observe the language skills development of the individuals over time, we can only estimate the pace of progress from the data we have by comparing the language skills of pupils who have been in the Czech Republic for different lengths of time. To estimate the speed of progress we used the method of linear regression, which allows us to estimate the parameters of regression equation

$$
\mathrm{Y}=\mathrm{a}+\mathrm{bX}
$$

where $Y$ is a dependent variable (in our case the attained level of language proficiency in the diagnostic test of language competences), $X$ is an independent variable (number of years the tested pupils spent in the Czech Republic), and coefficients $a$ and $b$ are the parameters of the regression equations. The regression equation can be expressed by a straight line that generally shows how the values of the dependent variables change in relation to the changes to the independent variables. We estimated the parameters of the regression equations separately for the three groups described in Table 4. The key parameter of the regression equation for us is coefficient $b$, which describes the slope of the line (coefficient $a$ is called the intercept and is not relevant in our case). The higher coefficient $b$ is, the greater the progress in attaining the language proficiency by the tested pupils in relation to the length of time of the pupil in the Czech Republic (see Table 5).

$8 \quad$ A tested pupil progressed to a higher level (A2, B1, B2) in each language skill only if he/she scored at least $60 \%$ in the lower level. 


\begin{tabular}{|l|c|}
\hline $\begin{array}{l}\text { Age of arrival in the } \\
\text { Czech Republic }\end{array}$ & $\begin{array}{c}\text { The slope of the regression line } \\
\text { (coefficient } b \text { ) }\end{array}$ \\
\hline $0-1$ years & 0,19 \\
\hline $10-11$ years & 0,33 \\
\hline 12 years and older & 0,46 \\
\hline
\end{tabular}

Table 5: The slope of the regression line describing progress in attaining language proficiency by the tested pupils in relation to the length of time of the pupil in the Czech Republic (the level is attained when the success rate of each language skill subtest is at least $60 \%$ )

It is clear from Table 5 that the slowest pace of progress in attaining language proficiency in relation to the number of years spent in the Czech Republic was observed among the lower secondary school pupils who were either born in the Czech Republic or moved to it at a very young age. In contrast, the most rapid progress was found among those lower secondary school pupils who moved to the Czech Republic at age 12 or over. The findings concur with the results of previous research suggesting that the process of attaining language skills is not linear, but instead follows a logarithmic curve - the pace of progress is the quickest in the years immediately after arriving in the Czech Republic, while the pace of progress slows down with the increasing number of years spent in the country. This general model of language acquisition development as identified by the diagnostic test was valid for all pupils regardless of their gender, age, or ethnic background (Kostelecká et al., 2013).

When language skill testing was organized among children at the lower secondary school level, the analysis of data suggested that children who were born in the Czech Republic (and therefore lived in the country for a relatively long time) were at that age already not improving their language skills as quickly as those who had come to the Czech Republic at a later age. This is logical, as the children who had lived in the country for a long time had reached or were close to the highest measurable level of language proficiency, and therefore, could not improve as quickly as those children whose language proficiency was generally at a lower level. These children had experienced the period in which language progress occurs most rapidly already when they were at an early school age or even a preschool age. Even if these children are still learning the Czech language, the pace of their language development is no longer measurable using our diagnostic instrument. Children who came to the Czech Republic between the ages of 10 and 11 were still making noticeable improving, even if they had already attained a relatively high level of proficiency. The most rapid progress was observed among children who had come to the Czech Republic in the oldest age category.

Finally, we were interested in how individual language skills developed among the tested children. We used the same method of estimating the progress as was described in the preceding part of the text. The results of the analysis are summarised in Table 6. The pace of the progress in language acquisition among the children who were born in the Czech Republic or came to it at a very young age is generally already very slow in the areas of speaking, reading and listening as the tested children had already mastered these language skills. The situation is different when the progress of this group of pupils in writing is considered - the pace of their progress is even quicker in this area than that of the other two groups of tested pupils. The ability to write correctly in Czech is evidently the most difficult of the tested language skills. This skill is generally acquired by children later than the other three tested skills. It seems that the ability to understand, speak and read in Czech must precede the effective learning of how to write. The attainment of language skills among the pupils that moved to the Czech Republic at age 12 or later generally progresses very quickly in the areas of listening and speaking, that is in the skills that are needed most in everyday life in the country that is their new homeland. The progress in reading and particularly the progress in writing is generally much slower in this group. It is possible that the learning of these "academic skills" will progress at a much quicker pace after their skills in the area of understanding and speaking reach some threshold level.

\begin{tabular}{|c|c|c|c|}
\hline \multirow[t]{2}{*}{$\begin{array}{l}\text { Type of } \\
\text { language } \\
\text { skills }\end{array}$} & 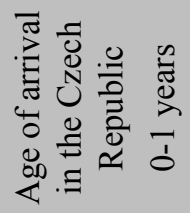 & 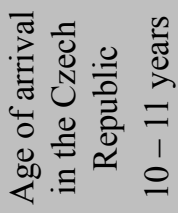 & 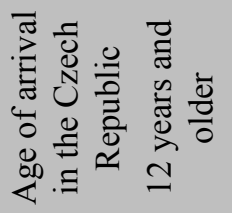 \\
\hline & \multicolumn{3}{|c|}{ The slope of the regression line (coefficient $b$ ) } \\
\hline Reading & 0,19 & 0,21 & 0,32 \\
\hline Writing & 0,38 & 0,32 & 0,13 \\
\hline Listening & 0,10 & 0,22 & 0,52 \\
\hline Speaking & 0,02 & 0,34 & 0,43 \\
\hline
\end{tabular}

Table 6: The slope of the regression line describing progress in attaining language proficiency by the tested pupils in relation to the length of time of the pupil in the Czech Republic by individual language skills

The relationships that were identified by the analysis of the information obtained with our diagnostic tests can, however, only be considered possible clues from which hypotheses could be formulated and properly tested by testing the language acquisition of a substantially larger sample of foreign pupils in Czech schools. Such language testing is scheduled in 2014, when our research team will test at least 400 pupils in both elementary and lower secondary schools in the Czech Republic. Greater number of children enrolled into the survey could increase the significance of correlation. The results of this testing will answer the question whether the above-described relations can be considered general trends.

\section{Discussion}

How our result are related to results of the other researchers? It is not easy question to be answered. While much attention is paid to the issue of the integration of immigrants into mainstream society both in the Czech Republic (e.g. Drbohlav and Dzúrová, 2007, Kušniráková and Čižinský, 2011) and in abroad (e.g. Djajic, 2003, Kasimis and Papadopoulos, 2005, King and Newbold, 2007, Ley, 2007), only limited number of studies has been devoted to the topic of integration of children of foreigners into schools in the host countries. Yet, many of the studies were theoretical scholarly publications (e.g. Průcha, 2007, 2011; Šindelářová, 2005, 2008, 2011) and only some of them were empirical studies based on surveys carried out in schools (e.g. Kocourek, 2001, 2002).

In the literature dealing generally with the linguistic integration of foreigners into host societies a number of hypotheses have been formulated concerning factors that influence the whole process. Chiswick and Miller (2001) mention among others exposure to the language, Beenstock et al. (2001) and Chiswick and Miller (2005) stress the linguistic distance of the 
immigrant's mother tongue from the language of the destination country. The data analysed in this article that come from surveys we conducted in 2011 at eight primary schools in Prague, allowed us to confirm the validity of both basic hypotheses. First, we proved that the language proficiency of foreigners in Czech schools was positively correlated with exposure to the Czech language (estimated as the amount of time the student had been in the Czech Republic). Second, we proved that the effectiveness of language acquisition related to the linguistic distance between the pupils' native language and Czech. Our analysis proved that children from a Slavic background reached the so-called threshold level, which is equal to a B1 level of language proficiency, as established by the CEFR, and which implies a certain level of independence in communication, more quickly in every language skill area than the children from an Asian background.

\section{Conclusion}

The results of this study prove that the process of acquiring language skills is critical for the integration of immigrant children into the educational system. Some children enter Czech schools with basically no knowledge of the language. At the time of the research, Czech legislation guaranteed intensive language courses for children from countries of the European Union only. The results showed that this assistance was not very effective. The vast majority of foreign children attending Czech schools come from non-EU countries (Russia, Ukraine, China and Vietnam). In 2012, Czech legislation was amended. Free preparation for entering the primary school system, including Czech language classes tailored to the needs of learners, is now extended to all foreigners, i.e. including students from countries outside the EU. The study results show that there is a significant difference between the needs of learners. Students from related linguistic areas reach the threshold level very quickly, whereas children with a very different language (in our case, children from Asia) reach the threshold level of all receptive skills quickly, but have big difficulties with productive skills. It is therefore necessary to focus on this area and pay attention to it in Czech language instruction.

\section{Acknowledgements}

This article is an extended version of the text that was presented at the international conference Efficiency and Responsibility in Education (Prague, 2013). It is an outcome of a research project Integration of the children of non-nationals into the Czech elementary schools financed by the Czech Science Foundation (registration number: 13-32373S). Some used data were collected with the support of the Ministry of Education, Youth and Sports.

\section{References}

Bachman, L. F., Palmer, A. S. (1989) 'The construct validation of self-ratings of communicative language ability'. Language Testing, vol. 6, no. 1, pp. 14-29.

Beenstock, M., Chiswick, B. R., Repetto, G. L. (2001). 'The Effect of Linguistic Distance and Country of Origin on Immigrant Language Skills: Application to Israel' ${ }^{`}$ International Migration, vol. 39, no. 3, pp. 33-60.

Carliner, G. (2000). The Language Ability of U.S. Immigrants: Assimilation and Cohort Effects. International Migration Review, 34, pp. 158-82.

Chiswick, B.R., Miller, P.W. (1996). Ethnic Networks and
Language Proficiency among Immigrants. Journal of Population Studies, 9, pp. 19-35.

Chiswick, B.R., Miller, P.W. (2001) 'A Model of DestinationLanguage Acquisition: Application to Male Immigrants in Canada'. Demography, vol. 38, no. 3, pp. 391-409.

Chiswick, B.R., Miller, P.W. (2005) 'Linguistic Distance: A Quantitative Measure of the Distance Between English and Other Languages. 'Journal of Multilingual and Multicultural Development, vol. 26, no. 1, pp. 1-11.

Coleman, J. S., Campbell, E. Q., Hobson, C. J., McPartland, J., Mood, A. M., Weinfeld, F. D., \& York, R. (1966). Equality of educational opportunity. Washington, D.C.

Council of Europe (2011) Common European Framework of Reference for Languages: Learning, Teaching, Assessment, [Online], Available: http://www.coe.int/t/dg4/linguistic/ Cadre1_en.asp [03 Jan 2013].

Cronbach L.J. (1951). 'Coefficient alpha and the internal structure of tests', Psychometrika vol. 16, no. 3, 297-334.

Cvejnová, J. (2006) 'Úroveň B1 - Prahová úroveň', in Štindlová, B. and Čemusová, J. (ed.) Sborník Asociace učitelù češtiny jako cizího jazyka (AUČCJ) 2005-2006, Praha: Akropolis.

Cvejnová, J., Papírníková, I. and Benešová Gruntová, D. (2007) Diagnostika úrovně znalosti českého jazyka: (diagnostická príručka), Praha: Centrum pro integraci cizinců.

Davies, A. (1990). Principles of language testing. Cambridge, Mass., USA: B. Blackwell.

Djajic, S. (2003) 'Assimilation of immigrants: Implications for human capital accumulation of the second generation', Journal of Population Economics, vol. 16, no. 4, pp. 831-845.

Drbohlav, D. and Dzúrová, D. (2007). 'Where Are They Going?: Immigrant Inclusion in the Czech Republic: (A Case Study on Ukrainians, Vietnamese, and Armenians in Prague)', International Migration, vol. 45, no. 2, pp. 69-95.

Drbohlav, D. et al (2010). Migrace a (i)migranti v Česku: kdo jsme, odkud přicházíme, kam jdeme?, Praha: Sociologické nakladatelství (SLON).

El-Hmoudová, D, Milková, E. (2012) 'Computer-based testing in the field of foreign language assessment'. In: Efficiency and Responsibility in Education 2012, Czech University of Life Sciences Prague, pp. 83-92.

Espinosa, K. E., Massey D. S. (1997). Determinants of English Proficiency among Mexican Migrants to the United States. International Migration Review, 31, pp. 28-50.

Harrison, A. (1983). A Language testing handbook. Reprint. London: Macmillan.

Hasselgreen, A. (2005) 'Assessing the language of young learners', Language Testing, vol. 22, no. 3, pp. 337-354.

Hayfron, J. E. (2001). Language Training, Language Proficiency and Earnings of Immigrants in Norway, Applied Economics, 33, pp. 1971-79.

Horn, R. V. (1993). Statistical Indicators: For the Economic and Social Sciences. Cambridge University Press.

Hughes, A. (2003) Testing for language teachers. 2nd ed. New York: Cambridge University Press.

Kasimis, Ch. and Papadopoulos, A.G. (2005) 'The multifunctional role of migrants in the Greek countryside: implications for the rural economy and society', Journal of Ethnic and Migration Studies, vol. 31, no. 1, pp. 99-127.

King, K.M. and Newbold, K.B. (2007) 'Internal migration 
dynamics of a Canadian immigrant gateway: Toronto as an origin, way-station and destination between 1991 and 2001 = La dynamique de la migration interne d'une porte d'entree canadienne: Toronto en tant qu'origine, etape et destination', The Canadian journal of regional science $=$ La revue canadienne des sciences régionales, vol. 30, no. 2, pp. 243-262.

Kocourek, J. (2001) 'Vietnamci V České republice' in Šišková, T. (ed.) Menšiny a migranti v České republice: my a oni v multikulturní společnosti 21. století, Praha: Portál, pp. 99-107.

Kocourek, J. (2002) Poznáváme svět dětí z Vietnamu: hledání společné řeči-: stručná př́ručka pro pedagogické pracovniky o podmínkách života dètí "nečeských" národností prijiždějících do $\check{C} R$ a o jejich vlasti, Plzeň: Foto and Tisk Znamenaný.

Kostelecká, Y., T. Kostelecký, J. Kohnová, K. Vojtíšková (2010) Integrace dětí př́slušníků národnostních menšin a cizinců do českého vzdělávacího systému. Závěrečná zpráva z projektu podpořeného $\mathrm{z}$ dotačního programu MŠMT na podporu vzdělávání $\mathrm{v}$ jazycích národnostních menšin a multikulturní výchovy, Praha: Univerzita Karlova v Praze, Pedagogická fakulta.

Kostelecká, Y., T. Kostelecký, J. Kohnová, M. Tomášová, K. Pokorná, K. Vodičková (2011) Integrace dětí př́slušniků národnostních menšin a cizinců do českého vzdělávacího systému. Závěrečná zpráva z projektu podpořeného z dotačního programu MŠMT na podporu vzdělávání v jazycích národnostních menšin a multikulturní výchovy, Praha: Univerzita Karlova v Praze, Pedagogická fakulta.

Kostelecká, Y., T. Kostelecký, J. Kohnová, M. Tomášová, K. Pokorná, K. Vodičková (2012) Integrace dětí př́slušniků národnostních menšin a cizinců do českého vzdélávacího systému. Závěrečná zpráva z projektu podpořeného z dotačního programu MŠMT na podporu vzdělávání v jazycích národnostních menšin a multikulturní výchovy, Praha: Univerzita Karlova v Praze, Pedagogická fakulta.

Kostelecká, Y., T. Kostelecký, J. Kohnová, M. Tomášová, K. Pokorná, K. Vojtíšková, M. Šimon (2013). Žáci-cizinci $v$ základních školách. Fakta, analýzy, diagnostika. Praha: Pedagogická fakulta Univerzity Karlovy, 179. s.

Kostelecká, Y. and Jančařík A. (2013) 'Factors influencing language proficiency of foreign children attending Czech primary schools'. Efficiency and Responsibility in Education 2013: Proceedings of the 10th International Conference, pp. 291-299.

Kuder, G. F., Richardson, M. W. (1937). The theory of the estimation of test reliability. Psychometrika, vol. 2 no. 3, 151160.

Kušniráková, T. and Čižinský, P. (2011) 'Dvacet let české migrační politiky: Liberální, restriktivní, anebo ještě jiná?', Geografie: sbornik České geografické společnosti, vol. 116, no. 4, pp. 497-517.

Ley, D. (2007) 'Countervailing Immigration and Domestic Migration in Gateway Cities: Australian and Canadian Variations on an American Theme', Economic Geography, vol. 83 , no. 3 , pp. 231-254.

Modood, T., R. Berthoud, J. Lakey, J. Nazroo, P. Smith, S. Virdee, and S. Beishnon. (1997). Ethnic Minorities in Britain. London: Policy Studies Institute.

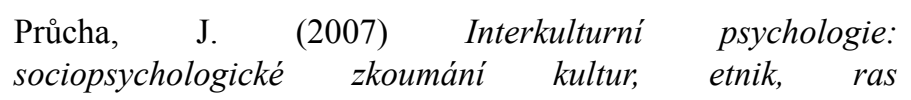

Průcha, J. (2011) Multikulturní výchova: př́ručka (nejen) pro ucitele, $2^{\text {nd }}$ edition, Praha: Triton.

Remennick, L. (2003) Language acquisition as the main vehicle of social integration: Russian immigrants of the 1990s in Israel, International Journal Of The Sociology Of Language, 2003, 164, pp. 83-105.

Smith, K. (1995) Assessing and Testing Young Learners: Can we? Should we? In Allen, D. (ed.), pp. 1-10.

Spiess, C. K., Büchel, F., \& Wagner, G. G. (2003). Children's school placement in Germany: does Kindergarten attendance matter?. Early Childhood Research Quarterly, vol. 18, no. 2, pp. 255-270.

Stevens, G. (1999). Age at Immigration and Second Language Proficiency among Foreign- Born Adults. Language in Society, 28, pp. 555-78.

Šára, M., Cvejnová, J., Confortiová, H., Čadská, M., Turzíková, M., Holub, J., Bischofová, J., Lánská, L. and Palková, Z. (2001) Prahová úroveñ - Čeština jako cizí jazyk, Strasbourg: Council of Europe.

Šindelářová, J. (2005) Socio-kulturní zázemí žáků a studentůimigrantů přicházejicích ze zemí s odlišnou kulturou: (přiručka pro učitele o vzdálených zemích, z nichž tito žáci a studenti přicházejí), Ústí nad Labem: Univerzita J. E. Purkyně.

Šindelářová, J. (2008) Čěstina jako cizi jazyk v evropském kontextu, Ústí nad Labem: Univerzita Jana Evangelisty Purkyně v Ústí nad Labem.

Šindelářová, J. (2011) Metodická doporučení $k$ začleňování žáků-cizinců do výuky v českých základních školách, [Online], Available: http://clanky.rvp.cz/clanek/c/Z/14329/metodickadoporuceni-k-zaclenovani-zaku-cizincu-do-vyuky-v-ceskychzakladnich-skolach.html/ [08 Jan 2013].

Tribalat, M. (1995). Faire France: Une Enque^te sur Les Immigre's et Leurs Enfants. Paris: La De'couverte.

Vallet, L. A., Caille, J. P. (1999) Migration and integration in France. Academic careers of immigrants' children in lower and upper secondary school. In European Science Foundation conference on Migrations and inter-ethnic relations in Europe, Obernai, France.

Van Tubergen, F, \& Kalmijn, M. (2005) Destination-Language Proficiency in Cross-National Perspective: A Study of Immigrant Groups in Nine Western Countries, American Journal Of Sociology, 110, 5, pp. 